\title{
表面反射を考慮した反射型TN液晶ディスプレイの セルギャップ測定
}

\author{
Cell-gap Measurement of Reflective TN-LCD while Considering Surface Reflection
}

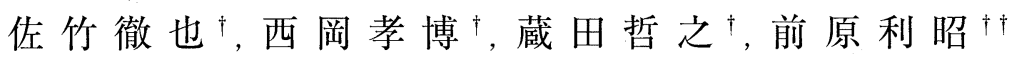
Tetsuya Satake $^{\dagger}$, Takahiro Nishioka ${ }^{\dagger}$, Tetsuyuki Kurata ${ }^{\dagger}$ and Toshiaki Maehara ${ }^{\dagger \dagger}$

Abstract A new cell-gap measurement method is described for reflective TN-LCD (twisted-nematic liquid crystal displays). We investigated reflected-intensity behavior in cell-gap measurement, which is based on reflective polarization analysis. The surface reflection of the sample was found to have a decisive influence on the obtained cell-gap value and was taken into account in the new method. The method showed good agreement with a transmissive cell-gap measurement in an experiment using a transmissive LC cell and external reflector. We applied it to microscopic cell-gap mapping using a microscope and a CCD camera system. The obtained map is consistent with the shape of the internal reflector.

$$
\text { キーワード：反射型液晶ディスプレイ，TN，セルギャップ，測定方法，表面反射 }
$$

\section{1.まえがき}

反射型液晶ディスプレイは，軽量，省電力，屋外での良 好な視認性などの点から，携帯電話，PDA（Personal Digital Assistant), 携帯ゲーム機などの携帯機器向けディ スプレイに用いられている. 現在の反射型液晶ディスプレ イの主流となっているのは，図1に示すような1枚偏光板方 式の反射型TN (Twisted Nematic) 液晶デイスプレイであ る1). 本方式の特徵としては，偏光板が上基板側にのみ用 いられていることと，反射板 (多くの場合，下部電極を兼 ねる) が液晶セル内に内蔵され，かつ反射板の表面にはミ クロンサイズの凹凸が設けられていることがあげられる。

また最近は，屋内，屋外を問わず良好な視認性が得られ る半透過型の液晶ディスプレイが携帯機器向けに用いられ るようになった。半透過型で現在主流となっているのは, 一つの画素内に反射部と透過部を設ける方式1)である，反 射部の基本的な構成は, 従来の 1 枚偏光板方式の反射型液 晶ディスプレイと共通である.

セルギャップは液晶層の厚みを示す数值で, 液晶ディス プレイの電気光学特性を左右する重要な設計パラメータで

\footnotetext{
2003年2月7日受付，2003年5月16日採録

†三菱電機株式会社 先端技術総合研究所

( ( 661-8661 尼崎市塚口本町8-1-1，TEL 06-6497-7496)

††名菱テクニカ株式会社 新事業推進室

（４ 461-8670 名古屋市東区矢田南5-1-14，TEL 052-723-7993)

$†$ Advanced Technology R\&D Center, Mitsubishi Electric Corp.

(8-1-1, Tsukaguchi-honmachi, Amagasaki, Hyogo, 661-8661, Japan)

$\dagger \dagger$ Meiryo Technica Corp.

(5-1-14, Yada-minami, Higashi-ku, Nagoya, Aichi, 461-8670, Japan)
}
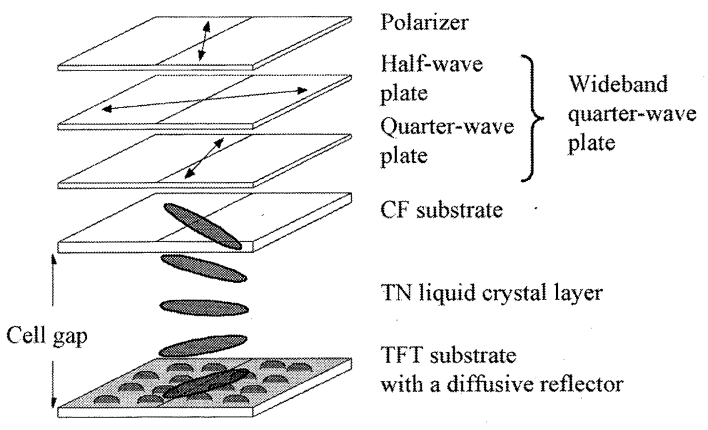

図 11 枚偏光板方式の反射型TN液晶ディスプレイの構成 Structure of the single-polarizer reflective TN-LCD.

ある.1枚偏光板方式の反射型 TN液晶ディスプレイでは, $3 \mu \mathrm{m}$ 前後に設計される。 またセルギャップは，製造現場に おいて，プロセス管理のための重要なパラメータでもある. 反射型液晶ディスプレイの場合，反射板の凹凸形状に対応 するミクロなセルギャップ分布の測定も求められている.

透過型液晶ディスプレイ，あるいは反射板を外付けした 反射型液晶ディスプレイのセルギャップ測定については, 透過偏光解析に基づく測定方法が多数提案され，多くの測 定装置が商品化されている.しかしながら，1枚偏光板方 式の反射型液晶ディスプレイの場合，反射板が内蔵されて いるため，透過偏光解析に基づく方法ではセルギャップを 測定することができない。

反射板を内蔵した反射型液晶ディスプレイのギャップ測 定法に関しては，これまでに反射偏光解析に基づく測定方 法が提案されている2) 7). 測定方法は二つに大別される. 
一つは平行ニコル配置と直交ニコル配置での反射光強度か ら算出する方法である ${ }^{2)}$ ４：二つの配置に加え，波長板を 挿入した場合や偏光子と検光子が $45^{\circ}$ の場合の反射光強度 を用いる方法もある.もう一つは直交ニコル配置における 消光位から算出する方法である5) 7).

平行ニコル配置と直交ニコル配置での反射光強度から算 出する方法では, 充分な測定精度が得られないと報告され ている2７）。これは，液晶ディスプレイのガラス表面での 表面反射光が, 平行ニコル配置での反射光強度にノイズと して加わるためである。

一方, 直交ニコル配置における消光位から算出する方法 では，表面反射光による影響は受けない．しかしながら， 凹凸反射板を内蔵する場合, 測定部位のセルギャップに分 布があるために, 消光位が精度よく計測できない. また本 方法は，測定時にサンプルの回転を要するため，顕微鏡を 用いた 2 次元セルギャップ分布の評価が容易ではない.

本論文では，平行ニコル配置と直交ニコル配置での反射 光強度を用いるセルギャップ測定法において，表面反射光 が測定值に与える影響を調べるとともに，表面反射を考慮 することによって，測定精度を改善した新しいセルギャッ プ測定法を提案する.

以下，2章では反射偏光解析に基づくセルギャップ測定 の基本原理について，3章では表面反射が測定精度に与え る影響について，4章では表面反射を考慮した新しい解析 法について記述する。さらに5章では, 新しい解析法を用 いたミクロな2次元セルギャップ分布評価について述べる.

\section{2. セルギャップ測定の基本原理}

液晶層を図2に示すように定義する。上基板側の液晶ダ イレクタ方向を基準とし，入射直線偏光の偏光方向を角度 $a$ （以下，入射偏光角 $a$ と呼ぶ）で定義する. 液晶層のツイ ス卜角を $\Phi$ とする. なお $\alpha, \Phi$ とも基板側の液晶ダイレ クタ方向に対して時計回り方向を正とする. セルギャップ は $d$, 液晶の複屈折は $\Delta n$, 測定波長は $\lambda$ とし, プレチルト

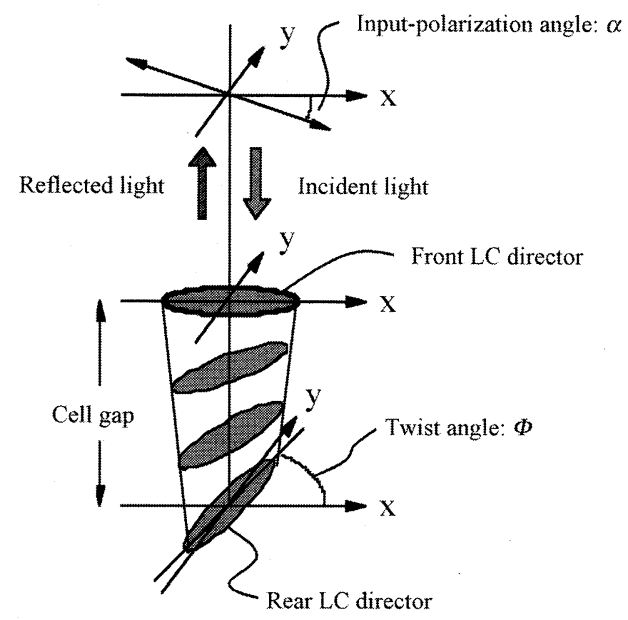

図 2 液晶層の定義

Definition of the liquid crystal layer.
角は無視する。

図2で定義された液晶層の反射率は, ジョーンズ行列法 によって式 (1) のように表現される ${ }^{8)} . R_{c}$ は出射側検光子 が入射偏光に対して直交ニコル配置の場合であり， $R_{p}$ は平 行ニコル配置の場合である.

$$
\begin{aligned}
& R_{c}=\left(\Gamma_{0} \frac{\sin X}{X}\right)^{2}\left\{\Phi \frac{\sin X}{X} \cos (2 \alpha)+\cos X \sin (2 \alpha)\right\}^{2} \\
& R_{p}=1-R_{c}
\end{aligned}
$$

ただし，

$$
\Gamma_{0}=\frac{2 \pi \Delta n d}{\lambda}, X=\sqrt{\Phi^{2}+\left(\frac{\Gamma_{0}}{2}\right)^{2}}
$$

である。

入射偏光角 $\alpha$, ツイスト角 $\Phi$, 液晶複屈折 $\Delta n$, 測定波 長 $\lambda$ が既知なら, 上記の反射率 $R_{c}, R_{p}$ はセルギャップdの みの関数である. したがって, 反射偏光解析によって反射 率が得られれば，七ルギャップを算出することができる.

図3に反射率 $R_{c}, R_{p}$ の計算結果を示す. ツイスト角 $\Phi$ は$70^{\circ}$, 液晶複屈折 $\Delta n$ は 0.071 , 波長 $\lambda$ は $546 \mathrm{~nm}$ とし, セル ギャップ $\mathrm{d} 2.5 \mu \mathrm{m}$ から $4.5 \mu \mathrm{m}$ まで $0.5 \mu \mathrm{m}$ おきに変えた. いずれのセルギャップの場合でも, 直交ニコル配置の反射 率 $R_{c}$ が 0 になる入射偏光角があり, かつ反射率 0 の入射偏光 角は $90^{\circ}$ 周期である。これは反射型のTN液晶層が一軸媒 質として振舞うことを示している ${ }^{5)}{ }^{6)}$. ま また, 反射率0の 入射偏光角 (消光位) は, セルギャップに依存して変化して おり，前章に記したように，消光位のみからセルギャップ を求めることが可能である.

平行ニコル配置においても, セルギャップが $3.0 \mu \mathrm{m}$ から

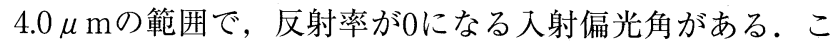
の範囲のセルギャップの場合, 反射型のTN液晶層は半波 長板として振舞うことを示している．通常，1枚偏光板方 式の反射型液晶ディスプレイでは, 反射型の TN液晶層は 半波長板になるように設計されるが，ツイスト角が $70^{\circ}$ の 場合, 非常に広いセルギャップマージンを有していること を示している。

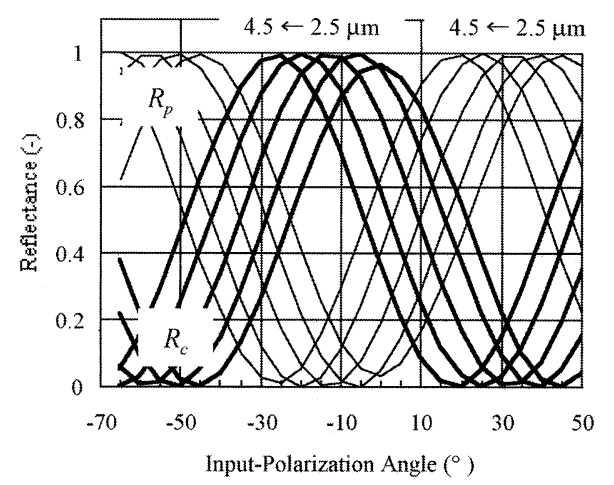

図 3 反射率の入射偏光角依存性（計算）

Calculated reflectance dependence on the input-polarization angle. 


\section{3. 表面反射の影響}

平行ニコル配置と直交ニコル配置での反射光強度を用い るセルギャップ測定法において, 反射率は二つの反射光強 度を規格化して求められる. 直交ニコル配置および平行ニ コル配置での反射光強度を $I_{c}, I_{p}$ とすると, $I_{c}, I_{p}$ は式 (2) で表される。

$$
\begin{aligned}
& I_{c}=L \times R_{c} \times A_{c} \\
& I_{p}=L \times R_{p}
\end{aligned}
$$

ここで，Lは入射光量， $A_{c}$ は測定系の偏光特性を補正する ためのパラメータである.

以下，式 (2) を用いた場合のセルギャップ測定の精度検 証実験について述べる。

\section{1 実験方法}

実験サンプルには，反射板を内蔵していない小型の透過 型液晶セルを用いた。液晶セルには偏光板，位相差フィル ムなども貼り付けられていない.ツイスト角 $\Phi$ は $-70^{\circ}$, 液晶複屈折 $\Delta n$ は0.071 (at 546nm) である。セルギャップd は，透過偏光解析 (回転検光子法)に基づく測定装置 (大塚 電子製RETS) で予め测定し， $3.22 \mu \mathrm{m}$ であった．反射偏光 解析時には，アルミをスパッ夕蒸着して作製した平面ミラ 一の上に液晶セルを載せて，反射型液晶セルとした.

測定装置には偏光顕微鏡を用いた。図4に測定装置の概 略を示す。測定波長は干涉フィルタによって $546 \mathrm{~nm}$ とした. 検出器には, ペルチェ冷却式の高階調CCDカメラ (16ビッ ト, 65,536階調)を用い, 面内平均強度を反射光強度とした. 反射光強度測定時は，偏光顕微鏡の入射側偏光子を固定し (偏光面がハーフミラー面に平行), 出射側検光子を直交二 コル，平行ニコルの各配置に回転させた．顕微鏡の回転ス テージを回すことにより, 入射偏光角 $a$ を変えながら, 反 射光強度 $I_{c}, I_{p}$ を測定した. なお, 本測定系での偏光特性 補正パラメータ $A_{c}$ は事前に測定を行い，1.12であった.

\section{2 実験結果}

図5に実験で得られた反射光強度 $I_{c}, I_{p}$ の入射偏光角 $a$ 依

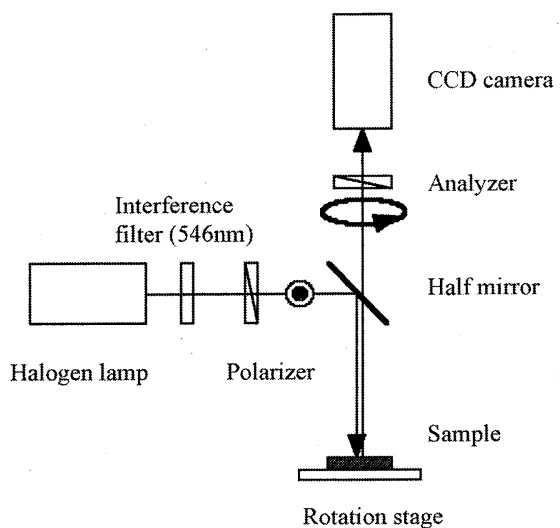

図 4 測定装置

Schematic diagram of the measurement system.
存性を示す。式 (2) を用いて，入射光量 $L$ とルギャップd をパラメータとして，フィッティングを行った。図5中実線 でフィッティングカーブを示す. 入射偏光角 $a$ がー $10^{\circ}$ 近 辺でフィッティングカーブのずれが大きいことが示された.

入射偏光角 $-10^{\circ}$ 近辺では, 平行ニコル配置での反射光 強度 $I_{p}$ は，小さいもののある程度の強度を有している。一 方，図5中のフィッティングカーブあるいは図3に示した反 射率の計算結果によると, 入射偏光角 $-10^{\circ}$ 近辺では平行

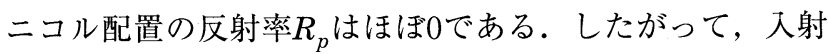
偏光角 $-10^{\circ}$ 近辺における平行ニコル配置の反射光強度 $I_{p}$ の主成分は，液晶セルガラス表面の表面反射光であると考 えられる。

図5の各入射偏光角における反射光強度から算出したセ ルギャップ值を図6に示す，入射偏光角 $-10^{\circ}$ 近辺におい て, セルギャップ值が大きく変化し, 透過偏光解析により, 事前に求めたセルギャップ值 $3.22 \mu \mathrm{m}$ から大きくずれるこ とが明らかになった。入射偏光角がー $10^{\circ}$ からはずれるほ ど，セルギャップ值の変動は小さくなった，表面反射光は， 入射偏光角によらず一定であると考えられるので, 平行二 コル配置での反射光強度 $I_{p}$ 中の表面反射光成分比に対応し て，図6のように測定值が変化していると考えられる.

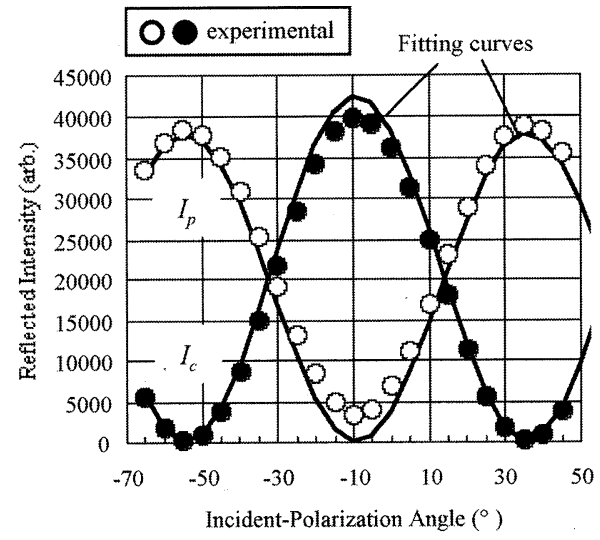

図 5 反射光強度の入射偏光角依存性 Measured reflected-intensity dependence on the input-polarization angle.

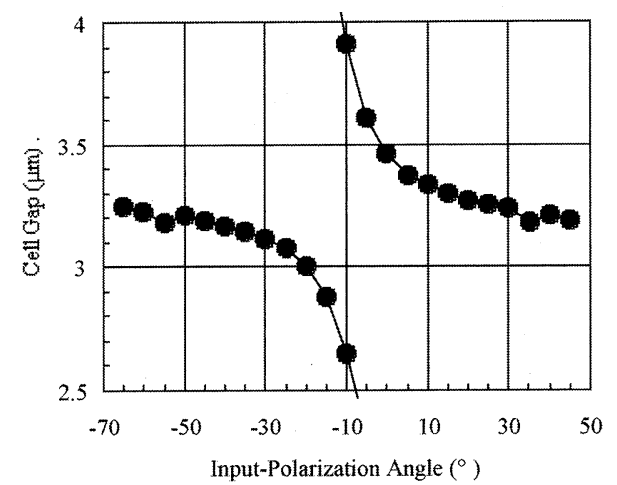

図 6 各入射偏光角での反射光強度から算出されたセルギャップ值 Cell gap calculated using mesured reflected intensities at each input-polarization angle. 


\section{3 精度検証実験まとめ}

以上のように，平行ニコル配置と直交ニコル配置での反 射光強度を用いるセルギャップ測定法では，得られるセル ギャップ值は，入射偏光角に依存して大きく変動すること が確認された．変動の原因は，平行ニコル配置での反射光 強度に含まれる表面反射光であると考えられる．表面反射 光の影響を抑えるために，測定時の入射偏光角を限定する 方法 (平行ニコル配置での反射光強度が小さくなるような 入射偏光角に設定しない)もあるが3)，測定精度がノイズ光 量の大小に依存して不安定であることから実用的とはいえ ない.

\section{4．表面反射を考慮した新しい解析法}

\section{1 表面反射の考慮}

今回，我々は平行ニコル配置と直交ニコル配置での反射 光強度を用いるセルギャップ測定法において，表面反射を 考慮した新しい解析法を考案した．図7にそのコンセプト を示す．入射光量 $L$ 面に扔いて反射されるので，この表面反射光量をSとして 新たに解析式に導入する. 入射光量Lから表面反射光量 $S$ を 差し引いた光量 $L-S か ゙$ 液晶層によって変調される，直行二 コル配置では，検出器には変調を受けた成分のみ検出され るが，平行ニコル配置の場合は，変調を受けた成分に加え て表面反射光 $S$ が検出される.

上記のコンセプトに基づく解析式は式 (3) で表現される.

$$
\begin{aligned}
& I_{c}=(L-S) \times R_{c} \times A_{c} \\
& I_{p}=(L-S) \times R_{p}+S
\end{aligned}
$$

\section{2 実験・解析}

解析式 (3) を用いて，再度，前章の実験結果の解析を行 った。図8に，実験データとあわせて，新しい解析法によ るフィッティングカーブを示す。フィッティング時には, 入射光量 $L$, セルギャップ $d$ に加え, 表面反射光 $S$ もパラメ ー夕とした．得られたフィッティングカーブは，すべての 入射偏光角にわたって実験データとよく一致した。フィッ ティングで得られたセルギャップ值は $3.21 \mu \mathrm{m}$ であり，透 過偏光解析による測定值 $(3.22 \mu \mathrm{m})$ とよく一致した。

$S / L$ で表される表面反射率は $8.4 \%$ であり，ガラス－空気 の単一界面としてはやや大きかった。原因は不明であるが, 他の界面 (例えば，液晶セルのガラス-ITO膜やITO膜液晶層の界面，あるいは顕微鏡内の界面）からの反射が影 響していると考えられる。

図8の各入射偏光角に㧍ける，反射光強度から式 (3) を用 いて算出したセルギャップ值を図9に示す．セルギャップ算 出に当たって，表面反射率 $S / L$ にはフィッティングで得ら れた值 $(8.4 \%)$ を用いた。入射偏光角によらず，ほぼ一定の セルギャップ值が得られた。また得られたセルギャップ值 は，透過偏光解析による測定值とよく一致した。ただし， より詳しく見ると，一部の入射偏光角 $\left(-55^{\circ},-10^{\circ}\right.$,

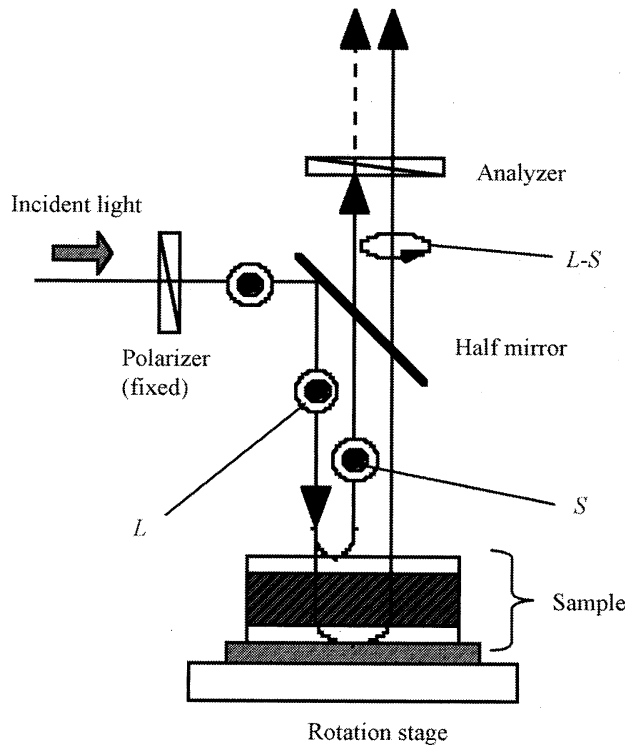

図7表面反射を考慮した新しい解析法のコンセプト Concept of the new analysis method with consideration of the surfacereflection.

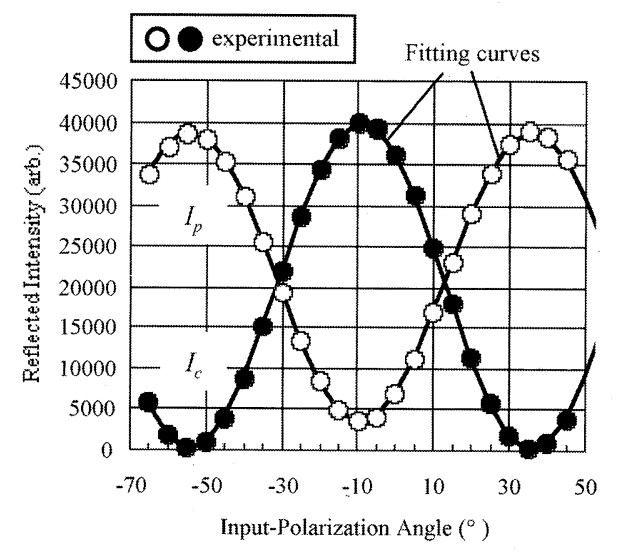

図8 新しい解析法によるフイッティング Fitting by new analysis method.

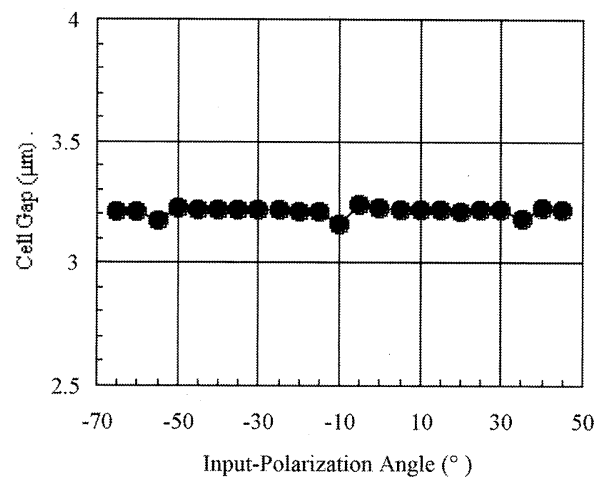

図 9 新しい解析法を用いて算出されたセルギャップ值 Cell gap calculated by new analysis method.

$\left.+35^{\circ}\right)$ ではややばらつきが見られた。これらの入射偏光角 に扔いては，直交ニコル配置あるいは平行ニコル配置のい ずれかの反射光強度が小さくなって扔り，表面反射光以外 の何らかの小さなノイズの影響を受けていると考えられる. 


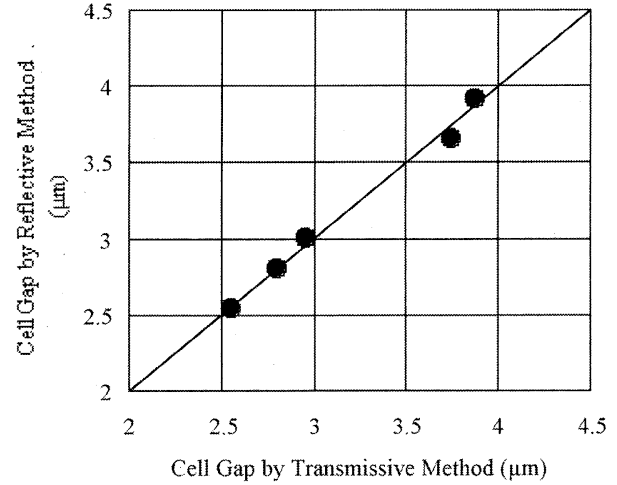

図10 透過偏光解析によるセルギャップ值との相関 Cell-gap correlation with the transmissive method.

次に，セルギャップを変えた幾つかの液晶セルを用意し， 同様の実験・解析を行った。 図10に透過偏光解析によるセ ルギャップ值と，新しい解析法を用いた反射偏光解析によ るセルギャップ値の相関を示す。なお，透過偏光解析には， SPM (Stokes Parameter Method) 法 ${ }^{10)}{ }^{11)}$ に基づく測定装 置 (名菱テクニカ製LCDアナライザLCA-LU4 $\left.{ }^{12}{ }^{13}\right)$ ) を用い た. 本装置も偏光顕微鏡を用いているので, 測定位置・面 積を反射偏光解析実験の場合とほほ同一にすることができ る，反射型TN液晶ディスプレイに用いられるセルギャッ プ範囲 $(2.5 \mu \mathrm{m} \sim 4.0 \mu \mathrm{m})$ において，両セルギャップ值は よく一致した.

以上のことから，平行ニコル配置と直交ニコル配置での 反射光強度を用いるセルギャップ測定法において, 表面反 射を考慮した新しい解析法を導入することにより，入射偏 光角に依らず，透過偏光解析でのセルギャップ值とほほ同 じ值が得られることが確認できた。

\section{2次元セルギャップ分布測定}

\section{1 評価手順}

前章で提案した新しい解析法を用いて，ミクロな2次元 セルギャップ分布の評価を試みた。測定装置は，3章と同 じ偏光顕微鏡システムを用いた。図11に評価手順を示す。

まず，入射偏光角を変えながら（回転ステージを回しな がら), ある特定の測定点での直交ニコル/平行ニコル配置 の反射光強度を測定し，表面反射率 $S / L$ を求める.

次に, 入射偏光角を固定し, 直交ニコル/平行ニコル配置 の反射光強度の面内分布をCCDカメラで測定 (撮影) する.

最後に，事前に得られた表面反射率 $S / L$ を用いて，面内 各点の反射光強度から，セルギャップを算出し，セルギャ ップ分布を求める.

なお，最初の表面反射率 $S / L$ 求めるステップにおいて， 前章までは，入射偏光角を 20 点以上変えて反射光強度を測 定したが， $\pm 10^{\circ}$ 以上異なる 3 点の入射偏光角での測定で 充分である ${ }^{14)}$

\section{2 実 験}

実験サンプルには，図12に示すような表面に凹部のある

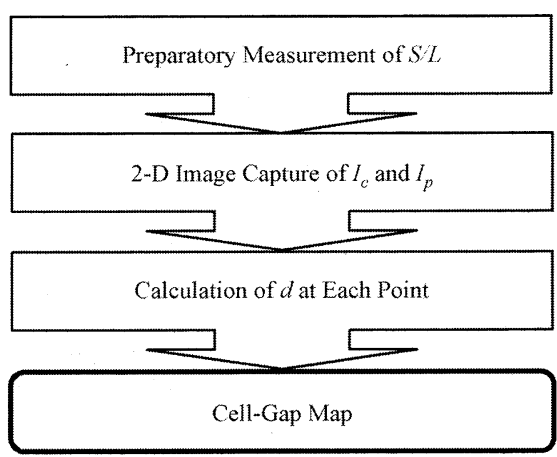

図11２次元セルギャップ分布評価手順

Procedure for 2-dimensional cell-gap mapping.

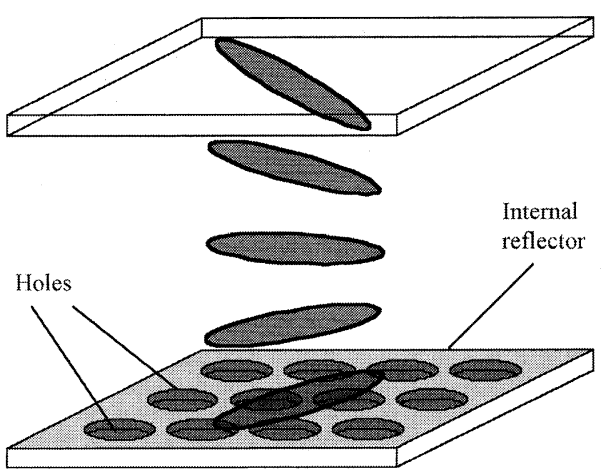

図12 セルギャップ分布評価用サンプル

Sample for 2-dimensional cell-gap mapping.

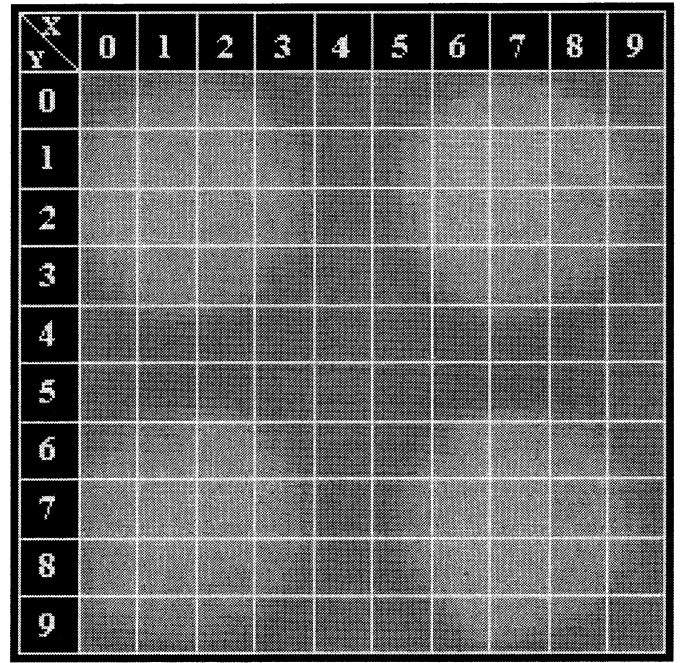

図13 セルギャップ分布評価エリア Photo of the evaluated area.

反射板を内蔵した小型の反射型液晶セルを用いた。液晶セ ル作製前の凹部の形状は，直径が $8.0 \mu \mathrm{m}$ ，深さが $0.35 \mu \mathrm{m}$ である。ツイスト角，液晶複屈折，測定波長は前章までの 透過型液晶セルと同じである．評価時には，図13に示すょ うに，測定範囲 $(18 \mu$ m 角 $)$ を100分割 $(10 \times 10)$ して解析し， セルギャップ分布を求めた。 


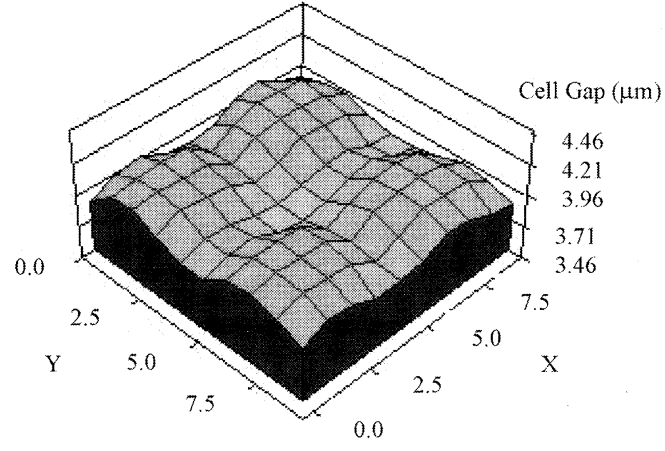

図14 2次元セルギャップ分布

Obtained 2-dimensional cell-gap map.

図14に得られたセルギャップ分布を示す。円形の凹部に 対応して円形の凸形状を有するセルギャップ分布が得られ た. セルギャップ分布において，凸部と平坦部のセルギャ ップ差は $0.26 \mu \mathrm{m}$ であり，元の山部の深さ $(0.35 \mu \mathrm{m})$ と一 致しなかった。これは，スピンコート塗布した配向膜の厚 さが平坦部と凹部で異なる（凹部の方が厚い）ためと考えら れる。

以上のように，新しい解析法を偏光顕微鏡システムに適 用することによって，内臓反射板の凹凸に対応するミクロ なセルギャップ分布の評価が可能であることが示された。

また，偏光顕微鏡を用いることで，通常の反射型TN液 晶ディスプレイのセルギャップ測定のみならず，画素サイ ズの小さいLCoS (Liquid Crystal on Silicon) デバイスのセ ルギャップ測定も可能であると考えられる。

\section{6.むすび}

反射偏光解析に基づく反射型 $\mathrm{TN}$ 液晶ディスプレイのセ ルギャップ測定において，液晶セルガラス表面の表面反射 光によって, セルギャップ測定值が大きく変動することを 確認した.

今回，表面反射を考慮した新しい解析法を提案した。透 過型液晶セルを用いた実験の結果，新しい反射偏光解析法 によって，透過偏光解析によるセルギャップ值とほほ同じ 值が得られることを示した。

さらに，偏光顕微鏡システムに本解析法を適用すること によって，内蔵反射板の凹凸構造に詨応したミクロな2次 元セルギャップ分布が得られることも示した.

\section{〔文 献〕}

1) N. Kimura : "High-Performance Reflective TFT-LCD", Proc. AMLCD'01, pp.55-58 (July 2001)
2) H.L. Ong: "Simple and Accurate Optical Reflection and Phase Compensation Methods for Reflective LCD Cell Gap”, SID 01 Digest, pp.430-433 (June 2001)

3) T. Satake, T. Nishioka, T. Kurata, and T. Maehara : "Novel Gap Measurement Method of Reflective LCD”, Proc. Asia Display/IDW'01, pp.185-188 (Oct. 2001)

4) D. Tanooka, S. Itoh, and I. Hirosawa : "Measurement Method for Cell Gap and Twist Angle of Reflective LCD”, Proc. IDW'02, pp.105-108 (Dec. 2002)

5) S. T. Tang and H. S. Kwok : "Measurement of Reflective LCD Cell Gap", Proc. IDW'00, pp.109-111 (Nov. 2000)

6) S. T. Tang and H. S. Kwok: "Measurement of Reflective Liquid Crystal Displays”, J. Appl. Phys., 91, pp.8950-8954 (June 2002)

7) W. K. Choi : "Reflective Liquid-Crystal Cell-Gap Measurement Using Input-Polarization-Angle Dependence”, SID 02 Digest, pp.530-533 (May 2002)

8) S. T. Wu and D. K. Yang: "Reflective Liquid Crystal Displays", John Wiley \& Sons, Ltd, Chichester, p.98 (2001)

9) S. Stallinga: "Equivalent Retarder Approach to Reflective Liquid Crystal Displays", J. Appl. Phys., 86, pp.4756-4766 (Nov. 1999)

10) Y. Zhou, Z. He, and S. Sato : "A Novel Method for Determining the Cell Thickness and Twist Angle of a Twisted Nematic Cell by Stokes Parameter Measurement", Jpn. J. Appl. Phys., 36, pp.2760-2764（May 1997)

11) Z. He, Y. Zhou, and S. Sato: "A Two-Dimensional Stokes Parameter Method for Determination of Cell Thickness and Twist Angle Distributions in Twisted Nematic Liquid Crystal Devices", Jpn. J. Appl. Phys., 37, pp.1982-1988 (Apr. 1998)

12) M. Okabe, M. Kaneko, T. Maehara, Y. Togashi, and S. Sato : "Evaluation of Cell Parameters of TN Liquid Crystal Cells by Using a Stokes Parameter Method", Mol. Cryst. and Liq. Cryst., 367, pp.771-778 (2000)

13）前原利昭，佐藤進：“透過型液晶セル検査装置LCDアナライザLCA LU4"，月刊ディスプレイ2001年12月号，7，pp.12-19（Dec 2001）

14) T. Satake, T. Nishioka, T. Kurata, and T. Maehara : "Reflective TN-LCD Cell-Gap Measurement Using Polarized Reflectance with Surface-Reflection Compensation”, Proc. Eurodisplay2002, pp.887-890（Oct. 2002)

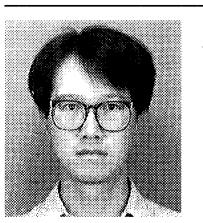

佐竹徹也 1991年, 京都大学大学院工学研究科工業 化学専攻修士課程修了。同年, 三菱電機（株）に入社. 以来，半導体デバイスのCVDプロセス開発に従事。1996 年より，液晶ディスプレイの開発に従事。

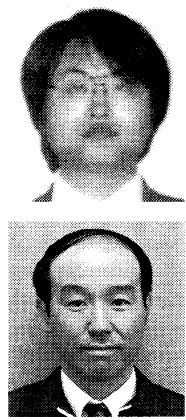

西凮势孝博 1992年，東京工業大学工学部有機材料工 学科卒業. 1997年, 同大学大学院博士課程修了. 同年, 三菱電機（株）に入社. 現在，主として液晶パネルの光 学設計扮よび評価技術開発を担当. 博士 (工学)。

蔵田哲之 1983年, 大阪大学大学院工学研究科応用 物理学専攻修士課程修了. 同年, 三菱電機（株）に入社. 以来，有機機能性材料の研究開発，液晶ディスプレイの 開発に従事. 工学博士。

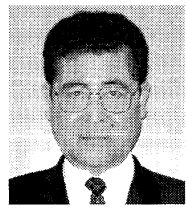

前原 利昭 1968年, 東京電機大学工学部電気工学科 卒業．同年，三菱電機（株）に入社．以来，工業用誘導 電動機の開発設計, 品質保証に従事. 1997年以降, 名菱 テク二カ株式会社にて液晶ディスプレイ検査装置の開発 設計に従事. 